\title{
Education in the Era of the Fourth Industrial Revolution: Development Vector, Prospects and Challenges for Russia
}

Dr Svetlana V. Ivanova ${ }^{\dagger}$ and Dr Oleg B. Ivanov ${ }^{* *}$

\section{Abstract}

Modern civilisation has entered the era of the fourth industrial revolution, characterised by digital, Internet and cyber-expansion, virtualisation, mobile technologies, robotisation, global changes in energy, nano- and biotechnologies. It entails significant changes in all spheres of human activity. There is a mass need for entirely new professions. Scientific and technological progress gives the society not only broad prospects but also brings new challenges and threats. There is a tight (not always fair) competition between the leading countries of the world and transnational corporations for domination in entering the sixth technological order, to lead in digital technologies and artificial intelligence. At this stage, educational systems should provide revolutionary changes based on the latest scientific achievements. One more dangerous threat is that the achievements of modern science and high technologies are not always used for the benefit of humanity, that is, large-scale cyber-attacks, hybrid wars, public consciousness manipulation. Form this point, the formation of a single global educational space, taking into account the humanistic needs of the society, seems really important. The fourth industrial revolution leads to personality changes and not always in a positive direction. This is especially true of the generation " $Y$ " or "network generation", consuming "intellectual fast food" and easily falling under the influence of others and becoming a victim of manipulation. It also includes the problem of virtual reality, which influences the person so profoundly that he/she falls out of the real world. Obviously, education must also undergo a systemic transformation, based on the characteristics of the modern information society and the globalising world that has entered the postmodern and mass media era. The issues mentioned above are deeply and critically analysed and discussed in this study both from the global and BRICS (precisely Russia) countries perspective. The authors eventually suggest some ways to solve them.

Keywords: Industrial Revolution; Education; BRICS Countries; Russia; Information Society

\footnotetext{
${ }^{\dagger}$ Professor, Scientific Director, Institute for Strategy of Education Development of the Russian Academy of Education \& Corresponding Member of the Russian Academy of Education, Email: sv_ivanova@instrao.ru

${ }^{*}$ Corresponding Author, Email: olbivanov@yandex.ru

¥ Professor \&Editor-in-Chief, Journal ETAP: Economic Theory, Analysis, Practice, Moscow, Russia

(C) 2020 Ivanova \& Ivanov. This is an Open Access article distributed under the terms of the Creative Commons Attribution License (http://creativecommons.org/licenses/by/2.0), which permits unrestricted use, distribution, and reproduction in any medium, provided the original work is properly cited.
} 


\section{Introduction}

The development of human civilisation is uneven. Several centuries have passed since the world entered the period of industrial society, which is characterised by the rapid development of industrial production and its dominance over the agricultural sector. However, already in the 1960s, the objective reality was associated with the entry of the humanity into a new postindustrial era, characterised by a fundamentally different structure of socio-economic organisation.

The founders of the theory of post-industrial society D. Bell (1999) and A. Toffler (1980) summarised the main characteristics of the new formation: changes in the priority types of economic activity (from the production of goods to the services); the growing role of science, education, public health; changes in the social norms (an agreement, tolerance instead of confrontation and war); new basis for decision making (scientific modelling and forecasting); informatisation of the society. As a result of hightech processes' introduction and large-scale production automation, the productivity of social labour has increased and employment in the direct manufacture of goods has decreased; the market has changed in the direction of demand for services.

However, modern civilisation is entering the era of the fourth industrial revolution accompanied by tremendous innovations in the digital sphere. This stage also requires revolutionary changes from education systems. Against this background, the approaches to vocational training are inevitably transformed. The fourth industrial revolution leads to the increase in the number of people employed in the intellectual spheres. It also influences the changes in the interests of the humanity towards creative development, stimulates the growth of educational needs, and, consequently, transformations in the very structure of the society. These processes require profound changes in the educational space, and, apparently, it is possible to predict the acceleration in the formation of the single world educational space (Tarman \& Chigisheva, 2017; Soltovets et al., 2020).

However, scientific and technological progress brings new challenges and threats. There is fierce competition for leadership between the leading states of the world, supranational groups and transnational corporations for entering the sixth technological order, digital technologies, artificial intelligence. Under these conditions, significant changes are required in the national education system, its close agglomeration with advanced science. This challenge is recognised at the level of government, science and education system as a whole.

The underestimation of humanisation and humanitarisation in the development of the society within scientific and technological progress becomes a big issue in the modern world. Therefore, it is necessary to form a humanistically oriented single educational space, based not only on the technical achievements, but also on the universal human moral values, ethical principles and humanistic needs of the individual.

This research begins with defining the research aim and objective of the study. This follows a brief discussion of the research methods and approaches adopted in this research. After that, it critically discusses the results and represents research conclusion.

\section{Objectives}

This study aims to identify trends in the impact of scientific and technological progress, the fourth industrial revolution on the education system; to consider the directions of the adequate education response to the urgent needs of the society and the challenges of the time. The main objective of this research is to study the negative impact of certain factors on civilisation connected with the introduction of modern scientific achievements and high technology and, accordingly, the consideration of measures to mitigate these risks, including humanitarisation of educational activities. The issues concerning the convergence of the educational systems of various states and the 
formation of a single world educational space are specifically studied.

\section{Research Methods}

The focus of the study is determined by the need to identify the place of the fourth industrial revolution in solving the socio-economic problems of the state, evaluate its impact on the education system and the formation of a single educational space, and consider the ways to improve the sphere of education in the modern world. In the framework of this study, the following research approaches and methods were used:

- factor analysis, that is, the identification of long-term determinants, a change in the educational trends of the modern world, their transformations;

- method for identifying cause and effect relationships;

- a spatial approach to predict changes in the development of education systems and educational space, to anticipate the emergence of new spaces and new forms of interaction in the field of education;

- structural and functional analysis in the study of pedagogical theory, educational practice and legislation governing the field of education;

- monographic and abstract logical methods;

- design method and forecasting method;

- method of expert assessments and other forms of scientific research.

\section{Results and Discussion}

\section{A Race for Leadership}

The new fourth industrial revolution engenders fierce competition between the states, economic unions and military and political blocs. Instead of consolidating the efforts to solve the global problems of the humanity, strengthening international institutions (UN, UNESCO, trade agreements, environmental conventions), a diametrically opposite process is observed, which causes the destruction of the unipolar world and the agonising attempt to preserve it.
Further stratification of the states is continuing in the modern world. Struggling to occupy a worthy place among the developed countries, it is necessary to clearly understand the current situation and form a strategy for moving forward and upward. Realistically assessing the situation, it should be noted that the BRICS countries today are within the framework of the fifth technological order. In contrast, the USA, some European countries and Japan have already entered the next technological phase (Ivanov, 2019).

According to the US experts, the share of the sixth technological order is approaching $5 \%$, the fifth is more than $60 \%$ and the fourth is $20 \%$. For comparison, in Russia, the share of the fifth technological order is only $10 \%$, the fourth is more than $50 \%$, and the third is $40 \%$ (Rebus \& Spivakova, 2019). This is a huge lag that might be overcome only due to a giant breakthrough.

The formation of a new technological order in the leading countries of the world has gone the usual way of developing the arms race. Stimulating the growth of a new technological order, the core of which is a complex of nano-, bioengineering and information and communication technologies, is developing in the field of production of military robots, uncrewed aerial vehicles, cognitive and cybernetic weapons (Glazyev, 2017).

For Russia, the main challenge is not only to remain a high-tech power, but to develop its scientific and technical potential in the shortest possible time. To achieve this goal, in accordance with May 7, 2018 Decree of the President of the Russian Federation No. 204 stated: "on the national goals and strategic objectives of the development of the Russian Federation for the period until 2024", national projects in the following areas should form the ground: education; labor productivity and employment support; science; digital economy and several others (Decree of the President of the Russian Federation dated May 9, 2017 No. 203 "On the Strategy for the Development of the Information Society in the Russian Federation for 20172030", 2017). 
Thus, the national project "Increasing the labor productivity and supporting employment" provides "the formation of the training system aimed at teaching the basics of improving labor productivity, including the use of digital technologies and platform solutions" (Federal business network. National project "Increasing labor productivity and employment support", 2019). The national project titled Science is aimed at creating a holistic system of training scientific and scientific and pedagogical personnel, including fifteen world-class scientific and educational centres and the formation of competitive teams (Federal business network. National project "Science", 2019). A special section of the national project - Digital Economy is also devoted to the aspects of personnel and educational decisions (Federal business network. National project "Digital Economy", 2019). Besides, training and qualification enhancement are at the core of other priority projects in the field of healthcare and culture.

The national education system itself has a goal to ensure global competitiveness in this area and Russia's entry into the top 10 countries in terms of general education quality. The national project - Education defines the strategy of this most important direction of the country's development for the next six years. It includes ten federal projects (see Figure 1), practically all the components and objectives related to the development of education to achieve all its aims.

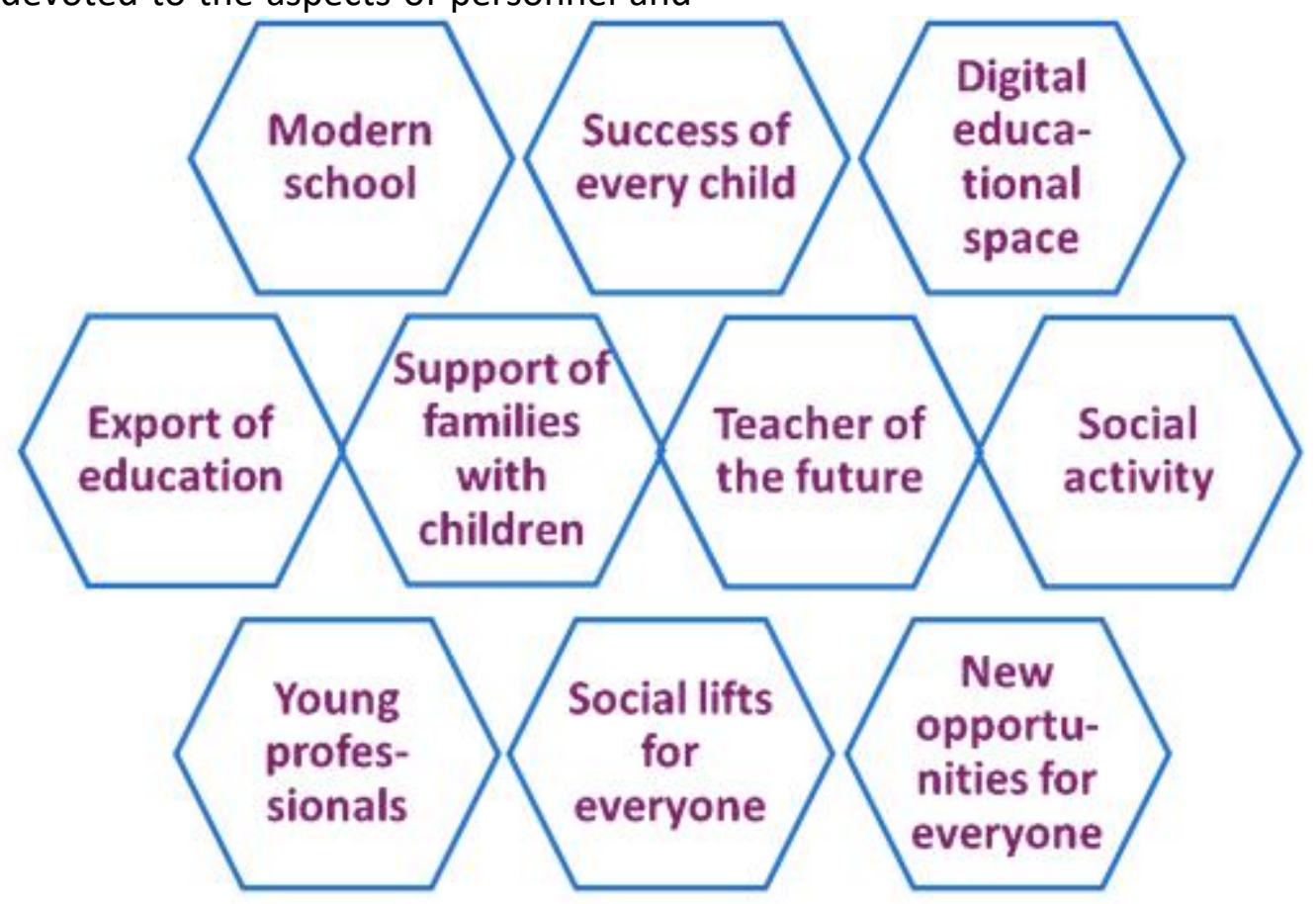

Figure 1. The Content of the National Project "Education"

Source: Authors using Federal Business Network. National Project, Education, 2019

The federal project - Modern School solves the ambitious objectives of radical re-equipping the material and technical base of educational institutions, the availability of quality education for all categories of students, and other significant challenges of our time (Federal business network. National project "Education", 2019).

"Modern Digital Educational Environment" makes it possible to solve the problem of mass provision of high-quality educational services regardless of the remoteness of their consumers (Federal business network. National project "Education", 2019).

Enormous opportunities for the modernisation of educational systems are opened due to the federal projects - Young professionals (improving the competitiveness of vocational education), New opportunities for everyone and Teacher of the future, which are focused on the formation 
of teaching staff for all levels of education in accordance with the challenges and demands of the modern era (the fourth industrial revolution, digital environment, media and postmodernism). The federal project Development of the export potential of the Russian education system is oriented towards Russia's entry into the single educational space (Federal business network. National project "Education", 2019).

No less significant for the creation of the system of quality modern education in Russia are other projects - Support for families with children, Social activity, Social elevators for everyone.

Considering the problem of the formation of a single educational space of the country and integration of domestic education into a single global educational space, we wish to apply a term that does not exist yet, but in our opinion, has a right to life, that is, a single scientific and educational space. The project Science provides for "ensuring the presence of the Russian Federation among the leading countries of the world carrying out R\&D projects in the areas determined by the priorities of scientific and technological development" (Federal business network. National project "Science", 2019). It aims at the training and professional growth of the scientific and pedagogical personnel, creation of at least 15 world-class scientific and educational centers; creation of "career lifts" mechanisms; inclusion of at least 500 Russian scientific journals into international databases by the end of 2024; bringing up to 4 thousand annual publications on the priority themes of scientific and technological development in the Q 1-2 journals included into international databases (Federal business network. National project "Science", 2019; Passport of the priority project "Universities as centers of the space for creating innovation", 2016).

In fact, these are private databases related to the state structures of individual countries, and, the materials are filtered to regulate the publication output and collect information, including a confidential one. They use only English and this excludes the articles and monographs in Russian, which obviously negatively affects the mass of publications and artificially lowers the assessment of the development level of the country's science and its scientists publishing in national languages (Strielkowski \& Chigisheva, 2018). However, the Russian language is one of the six official languages of the United Nations, therefore, it seems appropriate to form national ratings and scientific databases in addition to the universally recognised ones.

The advantages of scientific and technological progress are hardly disputable; instead, let us consider the adverse side effects, new threats and risks posed by the fourth industrial revolution.

In "The Global Risks Report 2019" (2019) the Davos forum experts identified 30 major global threats to humanity, noting that the main problems of our time, as in previous years, are still represented in the fields of environment and ecology, as well as in the technological and geopolitical spheres.

The group of global environmental risks is characterised by an increase in the number of emergencies, extreme weather conditions, human-related environmental disasters: chemical and biological pollution, oil spills, nuclear accidents. It is necessary to carry out large-scale training of environmental specialists, provide the mandatory inclusion of appropriate courses into the curriculum for all schoolchildren and all students, in both sciences and humanities. This is the context in which environmental education for sustainable development is being developed in all countries, including the Russian Federation, under the auspices of UNESCO (UNESCO, 2017).

The group of geopolitical risks deals with global issues related to proliferation and threat of weapon of mass destruction; the crisis of domestic and foreign policies of the states, political and military blocs; widespread of international organised crime, terrorism, corruption; interference of some states into the internal affairs of others; criminal militarypolitical pressure, and the implementation of the illegal sanctions policy; failures in global governance, weakening the influence of 
international institutions (including the UN, WTO), violation of agreements.

New global threats associated with the fourth industrial revolution are as follows: low efficiency of innovative technologies; malfunctions and failure of critical information systems; negative consequences of using the achievements of science and technology, cyber addiction and others. This also includes the massive theft of personal and other data and their unlawful use, large-scale cyber-attacks, hybrid wars, the use of the Internet to manipulate public consciousness, distorting information, the intentional use of social networks to spread misinformation. All these global risks, on the one hand, are closely related to the scientific and technological revolution and the increasing role of education in the modern world. On the other hand, they negatively affect the development of education and science.

Another severe problem and a significant group of modern global risks is the growth of fraud and corruption. Of the total economic crime, almost half is in cyberspace. According to the $\mathrm{FBI}$, losses from cybercrime in the USA amounted to \$2.7 billion, but according to experts, in 2019 losses from cyber fraud can reach $\$ 2$ trillion in the whole world (2018 Internet Crime Report, 2018).

The increase in the proportion of white-collar, intellectual crimes means a high level of education and specialised knowledge of the organisers, performers and developers of criminal schemes. This is a kind of challenge to the society, states and their educational systems. In our opinion, this challenge should be answered by creating a single world educational space, providing not only high-quality knowledge but also the development of personal qualities based on general humanistic moral values.

One of the growing threats of the fourth industrial revolution is the fact that introduction of advanced technology, robotics, information and communication technologies and other achievements is characterised by a large-scale reduction in the number of jobs. According to the ILO Director-General G. Ryder, the quality of jobs remains a big problem. There is a slowdown in decline in the number of working poor in developing countries, and unprotected employment, which involves about 1.5 billion people, still accounts for more than $46 \%$ of the total number of employed people in the world (International Labour Organisation, 2019).

The problem is bound to aggravate further. So, by 2030, 20.1 million people may lose their jobs as a result of robotisation, digitalisation and automation. Experts suggested that $73 \%$ of those employed in the hotel and restaurant business, $60 \%$ in manufacturing, $58 \%$ in agriculture and forestry, another $53 \%$ in retail and $51 \%$ in mining, would be at risk of automation (IA REGNUM, 2019).

Indeed, a solution to this problem is not only in the creation of new jobs, development and implementation of employment programs, but in the comprehensive measures for the personnel retraining and providing career guidance. It is necessary to actively work with young people, influencing their life choices and promoting new professions connected with robotics, digital technologies, artificial intelligence, the demand for which will be guaranteed for decades.

High unemployment and low living standards of population pose a whole series of risks: increasing social tension, protest moods; uncertainty about the future, depression, mental disorders; increase in crime; burden on the state due to the increase in government support for the non-working population. Therefore, the problem requires a comprehensive solution. Russia is well aware of the fact, as it is apparent from the goals and objectives of the national projects - Labor productivity and employment support and Education.

\section{Digital Technologies, Human Resources and Educational Space}

One of the main distinguishing features of the fourth industrial revolution is a widespread adoption of digital and information and communication technologies (ICT). The main policy document in this area today is the national project Digital Economy (2019) covering the 
period until 2024 with a budget of 1.8 trillion rubles. One of the most important blocks of the document is the federal project Personnel for the Digital Economy, which accumulates a set of measures to form a single digital educational space in the country. The project defines the main directions for providing the digital economy with competent personnel, supporting talented students as well as assisting the citizens in the development of digital literacy and the competencies for the digital economy.

It is supposed to solve the main problems and achieve the following project parameters: to develop the key digital economy competencies and the mechanism for their actualisation; to create a venture fund to support promising educational technologies; to create 50 centres for accelerated training of digital economy specialists; to create a free online service and programs for the mass development of digital literacy and to train 10 million people by 2025; as well as 1 million people in digital economy competencies in the framework of the state system of personal digital certificates (Federal Business Network. National project "Digital Economy", 2019).

No less ambitious tasks have to be solved during the implementation of the program in terms of supporting talented schoolchildren and students, the best educational institutions; developing digital training complexes, virtual laboratories ( 76 by the end of 2024 against 5 in 2019); developing experimental websites for their implementation etc. (Federal business network. National project "Digital Economy", 2019).

Thus, the formation of the digital educational space has the advantages, which are: the absence of territorial borders; the possibility of reaching the most remote parts of the country by the best lecturers, trainers and teachers; relatively low expenses per student. All these, of course, contribute to the high-quality and rapid formation and development of the personnel capacity of the new technological order as well as the harmonious entry of our modern education into a single global educational space.

\section{ICT and Human: Challenges of the Progress}

From the standpoint of classical methodology, information technologies provide a spectrum of opportunities for obtaining, assimilating and controlling significant volumes of knowledge. If we argue from the current position, then the amount of knowledge easily obtained by a person with a high level of ICT literacy and knowledge of IT equipment is not a determining factor in his/her professional success.

Knowledge becomes obsolete and is quickly forgotten. Today it is crucial not just to "know", but to be able to "acquire knowledge". The advantages of information and communication technologies used within distance learning are obvious. As negative trends may be considered not always high-quality training, ineffective forms of knowledge control, the use of distance learning as a legal form of a simplified way of obtaining a diploma and corresponding distrust to diplomas got on the basis of this form of training.

Another serious problem is the creation of virtual reality where the person is often immersed so profoundly that he/she "falls out" of the real world. More people get into a sensitive dependence on the Internet environment and the computer; the subject loses his/her inner world as a person, as an individual, remaining in the world of information, cognising reality through a modelled and changed world, subjected to the informational impact and psychological adjustments.

The next risk emerges from the fact that ICT has given rise to unique communication strategies with their own communication networks, communities and information management. New technologies bring positive impact: the development of distance learning, the creation of positive network communities that contribute to the improvement of the activities of both individual objects and subjects of the educational space, as well as its development as a whole. However, there is a negative side: manipulative practices, which are used as a tool for introducing distorted and fake information 
into people's minds, specific means of controlling individuals, communities and society.

Scientific and technological progress launched the process of psychological change in personality qualities. In the late $20^{\text {th }}$ Century, American scientists $N$. Hove and W. Strauss created the theory of generations that has been developed and gained popularity in recent years (Ivanov \& Ivanova, 2017b).

Generation " $X$ " (born from 1963 to 1983) is a generation of individualists with high working capacity, career-oriented people. Generation " $Y$ " (born between 1983-2003) is a generation of freethinkers focused on fast success today, selfrealisation and career growth, they love freedom and money as a new degree of freedom and gain knowledge and trust information received from the Internet more than from traditional sources (teachers and books).

The " $Z$ " generation (born after the mid-1990s) is a "postmodern product". Its representatives (in their mass) have superficial knowledge, prone to over-self-esteem, narcissism, are freedomloving individualists, egoists, who do not have a clear life position, being focused on the opinion of authoritative curators from the Internet networks and are dependent on the public network assessments (hence, the great importance is attached to selfies, likes, etc.). A classical teacher who tries to pass his knowledge on to his students no longer meets the requirements of the modern world. Any face-toface or online learner is ready to check the theses, facts and postulates reported by the teacher (Ivanova, 2014). Yet, the necessity in the new approaches to teaching, oriented on facilitating in dealing with a huge flow of information is solved not by the teacher-guru but by the companion, a senior comrade who helps to comprehend the goals of learning, find a path to the achievement and helps to achieve. Pedagogy finally becomes child-centred, and the individual's request for education often prevails over the needs of the society and the state. Is it correct? That is controversial. However, objectively the education system learns to suit generation $\mathrm{Z}$.
Another approach consists in combining the resources of science and education, deepening the contracting ability at the level of educational systems of the countries, the formation of a single educational space within the states and at the interstate level (Ivanov \& Ivanova, 2016). It is a powerful factor in reducing the negative impact of global social risks.

\section{Conclusion}

Our future is formed today, especially in this era of rapid changes. To develop a positive influence of ICTs in the educational space and to mitigate the risks, it is crucial to take into account the specificities of the new technologies:

- build a special ICT-based management system for ICT;

- organise specialised training for the subjects of educational space and society, teach them how to master these technologies, learn the nature and orientation of communicative strategies and build appropriate interaction;

- overcome the desire to refuse interaction in the format of a live dialogue as communication protects an individual from the negative impact of ICT and helps to avoid excessive virtualisation of life;

- finance the implementation of the programs to ensure a favorable impact and reduce the risks of the adverse impact of information and communication technologies on the objects and subjects of the educational space;

- counteract the negative impact of ICT on consumers' information dumps able to distort the real situation ("fake" news);

- deepen moral education, humanitarian training and the formation of moral values for all categories of students, paying particular attention to the students of specialities related to the information technology;

- improve the regulatory framework in the field of information technologies, including education (Ivanova, 2013; Ivanov \& Ivanova, 2017a). 
The critical part of the report of the Club of Rome is the idea of a new enlightenment, the so-called "education for the future" and the triumph of humanistic values (von Weizsaecker \& Wijkman, 2018).

The formation of a new attitude to the future of the humanity, the unity of humanistic thinking and a single world educational space rely on the stable development of civilisation and on whether we manage to overcome the existing global risks and threats. All of the above is closely related to the human factor. This awareness emphasises the role of education. We must be prepared for the fact that the tasks set within national projects on increasing the quality of education will be achieved in the conditions of global competition in this area.

\section{References}

Bell, D. (1999). The coming post-industrial society. Moscow: Academy.

Decree of the President of the Russian Federation dated May 7, 2018 No. 204 "On the national goals and strategic objectives of the development of the Russian Federation for the period until 2024". (2018). Retrieved on 9 September 2019 from, https://www.garant.ru/products/ipo/prime/do c/71837200/

Decree of the President of the Russian Federation dated May 9, 2017 No. 203 "On the strategy for the development of the information society in the Russian Federation for 2017-2030". (2017). Retrieved on 11 September 2019 from, http://www.consultant.ru/document/cons_doc _LAW_216363/

Glazyev, S.Yu. (2017). The battle for leadership in the 21st century. Russia-USA-China. Seven options for the foreseeable future. Moscow: Book world.

IA REGNUM. (2019). Over 20 million people in Russia may lose their jobs due to robots. Retrieved on 10 September 2019 from, https://regnum.ru/news/economy/2713871.ht $\mathrm{ml}$
International Labour Organisation. (2019).

Retrieved on 8 September 2019 from, http://www.ilo.org/global/lang--en/index.htm

Ivanov, O.B. (2019). The modern world: global trends, challenges and threats. Journal ETAP:

Economic Theory, Analysis, Practice, 1, 20-36.

Ivanov, O.B., \& Ivanova, S.V. (2017a).

Educational space in the modern world: The interdisciplinary aspect. Revista Espacios, 38(40), 19.

Ivanov, O.B., \& Ivanova, S.V. (2017b). The impact of global risks and challenges on the education systems and formation of a single global educational space. In Federal Directory. Education in Russia. Vol. 12. (p. 31-38). Moscow: NP "Center for Strategic Partnership". Ivanova, S.V., \& Ivanov O.B. (2016). Society demands for the quality of education as a factor of modern education space forming. SHS Web of Conferences, Vol. 29, 01028. Retrieved on 9 September 2019 from, https://www.shsconferences.org/articles/shsconf/pdf/2016/07/ shsconf_eeia2016_01028.pdf

Ivanova, S.V. (2014). Electronic future of the educational space: the pros and cons. Open School, 7, 19-23.

Ivanova, S.V. (2013). To the question on the influence of information and communication technologies on the educational space. Space and Time, 3, 72-75.

National project "Digital Economy". (2019).

Retrieved on 8 September 2019 from, https://strategy24.ru/rf/management/projects/ natsional-nyy-proyekt-tsifrova-ekonomika

National project "Education". (2019). Retrieved on 8 September 2019 from, https://strategy24.ru/rf/education/projects/nat sional-nyy-proyekt-obrazovaniye

National project "Increasing labor productivity and employment support." (2019). Retrieved on 8 September 2019 from, https://strategy24.ru/22/communication/proje cts/podderzhka-zanyatosti

National project "Science". (2019). Retrieved on 8 September 2019 from, 
https://strategy24.ru/rf/innovation/projects/na tsional-nyy-proyekt-nauka

Passport of the priority project "Universities as centers of the space for creating innovation". (2016). Approved by the Presidium of the Presidential Council for Strategic Development and Priority Projects - Protocol No. 9, October 25, 2016. Retrieved on 6 September 2019 from, http://www.consultant.ru/document/cons_doc _LAW_216430/

Rebus, N.A., \& Spivakova, N.Ya. (2019). Human capital during the transition to the $\mathrm{VI}$ technological order. Journal ETAP: Economic Theory, Analysis, Practice, 4, 78-89.

Soltovets, E., Chigisheva, O., \& Dmitrova, A. (2020). The role of mentoring in digital literacy development of doctoral students at British universities. Eurasia Journal of Mathematics, Science and Technology Education, 16(4), em1839.

Strielkowski, W., \& Chigisheva, O. (2018). Research functionality and academic publishing: Gaming with altmetrics in the digital age. Economics and Sociology, 11(4), 306-316.

Tarman, B., \& Chigisheva, O. (2017). Transformation of educational policy, theory and practice in post-soviet social studies education. Journal of Social Studies Education Research, 8(2), I-IV.

The Global Risks Report 2019. (2019). Retrieved on 22 August 2019 from, http://www3.weforum.org/docs/WEF_Global_ Risks_Report_2019.pdf

Toffler, E. (1980). The third wave. Retrieved on 9 September 2019 from, https://www.6lib.ru/books/tret_a-volna155490.html

UNESCO. (2017). Accountability in education: meeting our commitments; Global education monitoring report, 2017/8. Retrieved on 19 August 2019 from, https://unesdoc.unesco.org/ark:/48223/pf0000 259338

von Weizsaecker, E., \& Wijkman A. (2018). Come On! Capitalism, Short-termism, Population and the Destruction of the Planet A Report to the Club of Rome. New York: Springer.

2018 Internet Crime Report. (2018). Retrieved on 7 September 2019 from, https://pdf.ic3.gov/2018_IC3Report.pdf 